\title{
UJI EFEKTIVITAS KOMPARTEMEN DASAR UNTUK PEMBESARAN LOBSTER PASIR (Panulirus homarus) DI PANTAI SEPANJANG, KABUPATEN GUNUNG KIDUL
}

\author{
SEA CAGE EFFECTIVENESS TEST FOR SPINY LOBSTER (Panulirus homarus) \\ IN SEPANJANG COAST, GUNUNG KIDUL DISTRICT
}

\author{
Umi Anissah, Amin Pamungkas, Waryanto dan Sri Suryo Sukoraharjo \\ Pusat Pengkajian dan Perekayasaan Teknologi Kelautan dan Perikanan \\ Badan Penelitian dan Pengembangan Kelautan dan Perikanan \\ Gedung II Balitbang KP lantai 5, Jl. Pasir Putih I, \\ Ancol Timur, Jakarta Utara 14430 Indonesia \\ Tel: (+62-21) 64700926, Fax: (+62-21) 64700926 \\ E-mail: anis_jogja@yahoo.com, aminphe@gmail.com, waryanto_c2@yahoo.com, srisuryo@gmail.com \\ Diterima tanggal: 4 Maret 2015, diterima setelah perbaikan: 20 Juli 2015, disetujui tanggal: 30 Juli 2015
}

\begin{abstract}
ABSTRAK
Tingginya permintaan lobster laut di pasar nasional maupun internasional serta adanya pembatasan ukuran lobster yang boleh ditangkap dari alam menyebabkan tingkat ketersediaan lobster di pasaran menjadi berkurang, di sisi lain, kegiatan budidaya maupun pembesaran lobster belum berkembang dengan baik. Oleh karena itu, diperlukan suatu penelitian terkait dengan pembesaran lobster. Penelitian pembesaran lobster di alam tidak terlepas dari teknologi kompartemen yang digunakan, untuk itu penelitian mengenai rekayasa teknologi kompartemen pembesaran lobster laut penting untuk dilakukan. Tujuan penelitian ini adalah mengetahui tipe kompartemen yang paling efektif untuk pembesaran lobster pasir di Pantai Sepanjang, Yogyakarta dengan melakukan pengukuran berat dan panjang karapaks lobster. Hasil dari penelitian ini menunjukkan bahwa kompartemen lobster yang paling efektif untuk pembesaran lobster pasir adalah kompartemen berbentuk silinder, dengan ukuran $200 \mathrm{lt}$ dan diameter lubang pada selimut tabung $3 \mathrm{~cm}$ dibandingkan dengan kompartemen kontrol dan seluruh kompartemen modifikasi.
\end{abstract}

Kata kunci: kompartemen dasar, lobster pasir (Panulirus homarus), Pantai Sepanjang.

\section{ABSTRACT}

The high demand of sea lobster and the restrictions on the size of lobsters that can be captured caused lobster on the market to be a rarity, on the other hand lobster's mariculture activities are not developed yet. Therefore, a study related to the growing-out lobster is needed. Research of lobster's grow-out can not be separated from the compartment technology, the study of engineering technology of lobster enlargement become an important research to do. The aim of this research was to determine the best fixed seacage type for scalloped spiny lobster enlargement in Sepanjang Coast, Yogyakarta City through measuring the weight and length of the lobster's carapace. The results shown that the most effective lobster fixed seacage to enlarge scalloped spiny lobster were cylinder, with 200 liters of size and $3 \mathrm{~cm}$ diameter of hole in the blanket tube compared to the control fixed seacage and the entire fixed seacage modification.

Keywords: fixed seacage, scalloped spiny lobster (Panulirus homarus), Sepanjang Coast.

\section{PENDAHULUAN}

Lobster laut merupakan komoditas yang bernilai tinggi baik di pasar nasional maupun internasional. Secara global, permintaan lobster laut naik sekitar $15 \%$ per tahun. Kenaikkan permintaan ini digerakkan oleh pasar internasional, terutama Cina. Di Indonesia, lobster diekspor oleh pusat-pusat niaga di Bali dan Surabaya (Jones, 2008). Teknologi perekayasaan sarana budidaya lobster laut telah dilakukan di beberapa negara dunia, akan tetapi belum dapat diaplikasikan secara global. Hal ini dikarenakan perbedaan jenis lobster dan kesesuaian dengan kondisi lingkungan di berbagai negara. Indonesia sebagai negara kepulauan dengan beragam kondisi pantai merupakan daerah endemik udang karang atau biasa disebut lobster.

Di Indonesia terdapat sekitar enam jenis lobster yang merupakan spesies asli, diantaranya 
Panulirus homarus, $P$. longipes longipes, $P$. ornatus, $P$. penicillatus, $P$. polyphagus dan $P$. versicolor. Lobster yang umum dibudidaya adalah lobster pasir (Panulirus homarus) dan lobster mutiara $(P$. ornatus). Lobster pasir merupakan spesies yang dominan dan populasinya 3 hingga 9 kali lebih besar dari lobster mutiara (Jones, 2008). Keberagaman jenis lobster yang banyak menjadi modal bagi Indonesia untuk menjadi salah satu pengekspor lobster terbesar di Asia, hal ini tentunya harus didukung dengan inovasi teknologi yang mendukung kegiatan industrialisasi budidaya lobster.

Kegiatan budidaya lobster berskala komersial dan ekperimental telah dimulai oleh sejumlah negara diantaranya New Zealand, Jepang, Australia, India dan Vietnam (Jeff \& Davis, 2003). Bebeberapa diantaranya menggunakan sistem sea cage dengan berbagai material dan desain. Beberapa faktor yang menentukan keberhasilan budidaya udang karang dengan sistem sea cage adalah desain dan pemilihan lokasi budidaya (Mohammed et al., 2010). Penggunaan material penyusun sea cage yang digunakan di berbagai negara sangat beragam, India mengembangkan sea cage dengan bahan dasar rangka High Density Polyetylen (HDPE) yang dilengkapi dengan net berbahan nilon. New Zealand mengembangkan sea cage skala eksperimen berbahan dasar HDPE berbentuk silinder dan kotak untuk memelihara bibit lobster dengan ukuran panjang karapaks 40-55mm (Jeff \& James, 2001). Vietnam mengembangkan sea cage sistem submerge dari material kayu dan besi serta material lain yang mudah dijumpai di daerah budidaya (Hung \& Tuan, 2009).

Di Indonesia kegiatan budidaya maupun pembesaran lobster laut belum banyak dilakukan, sebagian besar lobster laut diperoleh dengan penangkapan lobster laut dari alam. Pembesaran lobster mulai berkembang di beberapa daerah antara lain Lombok, Pelabuhan Ratu dan Aceh. Sistem pembesaran lobster pada kawasan tersebut menggunakan Keramba Jaring Apung (KJA) dengan material dari bambu dan kayu. Di wilayah Kabupaten Sukabumi, khususnya kecamatan Pelabuhan Ratu sudah dikembangkan usaha pembesaran lobster dengan menggunakan KJA berbahan dasar HDPE. Saat ini, penggunaan KJA untuk pembesaran lobster dianggap tidak optimal karena lobster hanya mendiami dasar kolom air. Berdasarkan keadaan ini, maka diperlukan inovasi untuk pembesaran lobster yang lebih baik. Inovasi tempat pembesaran/kompartemen dasar lobster diharapkan menjadi bagian penyelesaian dalam melakukan pembesaran lobster laut.

Perairan pantai selatan Kabupaten Gunung Kidul dan Kabupaten Pacitan merupakan daerah penangkapan dan pemanfaatan lobster laut (Hargiyanto et al., 2013). Persentase produksi lobster pasir (Panulirus homarus) di daerah ini mengalami penurunan dari tahun 2001-2008 (Pusat Penelitian Pengelolaan Perikanan dan Konservasi Sumberdaya Ikan, 2012). Penurunan produksi ini diduga merupakan salah satu akibat dari tekanan penangkapan yang terjadi. Dampak lain dari tekanan penangkapan adalah semakin mengecilnya ukuran lobster yang tertangkap (Hargiyanto et al., 2013). Untuk mengantisipasi fenomena tersebut dan kemungkinan terjadinya 'lost generation' lobster, maka pada tanggal 7 Januari 2015, Kementerian Kelautan dan Perikanan RI melarang penangkapan dan penjualan lobster dengan ukuran karapaks di bawah $8 \mathrm{~cm}$ melalui Permen-KP No 1/PERMEN-KP/2015. Lobster kecil yang tertangkap oleh nelayan harus dibesarkan terlebih dahulu hingga mencapai ukuran yang diijinkan untuk dijual. Penggunaan kompartemen dasar untuk pembesaran lobster yang ditempatkan di laut, diharapkan dapat menghasilkan pertumbuhan lobster yang tinggi dengan tingkat kelangsungan hidup yang tinggi pula. Hal ini dimungkinkan karena pembuatan kompartemen dan penempatannya diusahakan untuk mendekati kondisi alamiah pertumbuhan lobster. Penelitian teknologi kompartemen pembesaran lobster yang efektif menjadi penting untuk dilakukan dan diperhatikan.

\section{BAHAN DAN METODE}

Kegiatan penelitian ini dilaksanakan di Pantai Sepanjang, Kabupaten Gunung Kidul, Propinsi Daerah Istimewa Yogyakarta. Pengambilan data dilakukan pada Bulan Oktober-Desember 2014.

\subsection{Persiapan}

a. Pembuatan Kompartemen Dasar Lobster Kompartemen lobster beserta pemberatnya dibuat dengan memodifikasi bentuk yang sudah dipakai selama ini di lokasi penelitian. Pembudidaya lobster pasir di Kabupaten Gunung Kidul selama ini melakukan pembesaran lobster pasir 
menggunakan silinder (blong) 30 liter berbahan HDPE, sedangkan pemberat dibuat menggunakan semen dengan kerangka besi. Modifikasi kompartemen lobster dikembangkan berdasarkan kompartemen lobster yang sudah dipakai di lokasi. Modifikasi dilakukan pada ukuran tabung dan diameter lubang pada selimut tabung. Dalam penelitian ini dibuat
4 tipe kompartemen dan 1 tipe kompartemen kontrol. Setiap tipe kompartemen dibuat 2 buah dengan spesifikasi dan kondisi lingkungan perairan yang diasumsikan sama. Secara detail, modifikasi kompartemen lobster disajikan dalam Tabel 1, sedangkan desain rekayasa kompartemen disajikan dalam Gambar 1.

Tabel 1. Modifikasi kompartemen dasar budidaya lobster pasir

Table 1. Fixed seacage modification for scalloped spiny lobster mariculture

\begin{tabular}{ccccccc}
\hline Kode & Bentuk & $\begin{array}{c}\text { Volume } \\
(\mathbf{L t})\end{array}$ & $\begin{array}{c}\text { Diameter lubang } \\
(\mathbf{c m})\end{array}$ & Pola lubang & $\begin{array}{c}\text { Jarak antar titik } \\
\text { pusat lubang }(\mathbf{c m})\end{array}$ & Bahan \\
\hline A & Silinder & 30 & 0.5 & Tidak teratur & 2 & Plastik HDPE \\
B & Silinder & 30 & 2 & Teratur & 4 & Plastik HDPE \\
C & Silinder & 30 & 3 & Teratur & 4 & Plastik HDPE \\
D & Silinder & 200 & 2 & Teratur & 4 & Plastik HDPE \\
E & Silinder & 200 & 3 & Teratur & 4 & Plastik HDPE \\
\hline
\end{tabular}

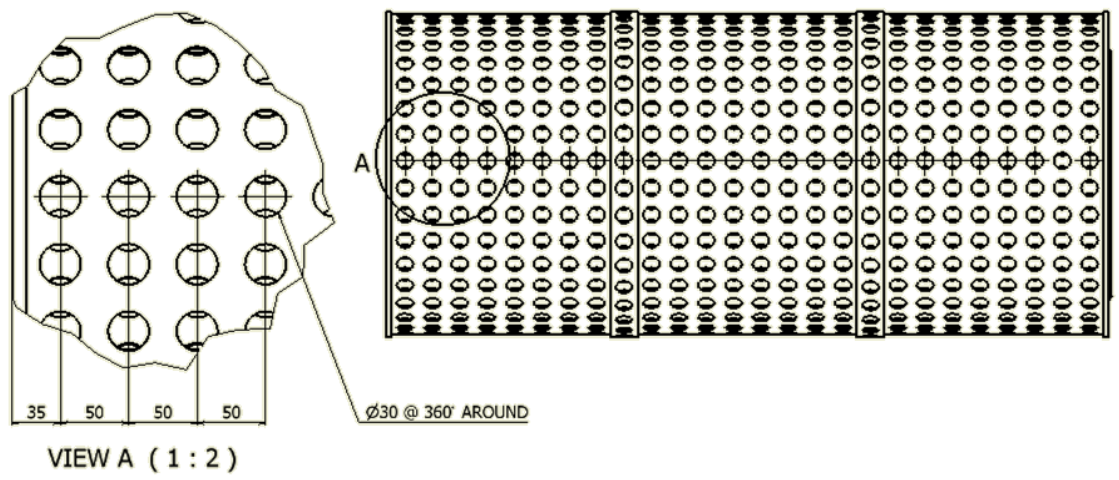

(a)

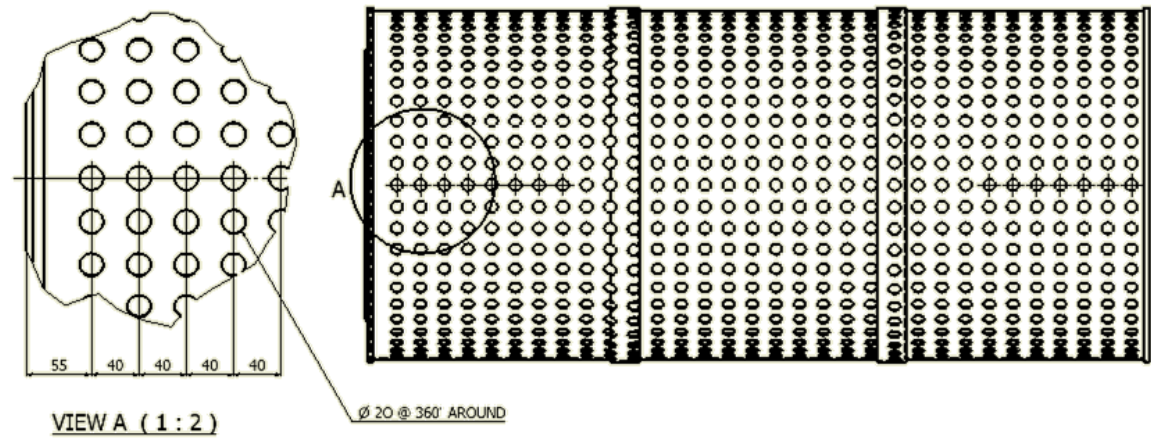

(b)

Gambar 1. Disain prototipe keramba dasar dengan diameter lubang $3 \mathrm{~cm}$ (a) dan $2 \mathrm{~cm}$ (b)

Figure 1. Fixed seacage design with hole's diameter $3 \mathrm{~cm}(a)$ and $2 \mathrm{~cm}(\mathrm{~b})$ Sumber: Hasil perancangan 
Sedangkan jumlah lobster yang dibesarkan untuk tiap-tiap kompartemen disajikan dalam Tabel 2.

Tabel 2. Jumlah lobster dalam kompartemen

Table 2. The number of lobsters in the seacage

\begin{tabular}{cc}
\hline Tipe Kompartemen & Jumlah Lobster (ekor) \\
\hline A & 9 \\
B & 10 \\
C & 10 \\
D & 15 \\
E & 15 \\
\hline
\end{tabular}

Sumber: Hasil pengukuran

b. Bibit Lobster

Pengujian efektifitas kompartemen untuk pembesaran lobster menggunakan lobster pasir sebagai spesies yang diujicobakan. Spesies ini dipilih karena tingginya kemampuan adaptasi lobster pasir terhadap perbedaan lingkungan perairan (Thao, 2012). Bibit lobster pasir didatangkan dari Lombok, Nusa Tenggara Barat menggunakan metode pengiriman kering. Lobster yang digunakan sebagai benih berukuran 20-50 gr per ekor. Rata-rata berat benih yang digunakan 31,45 gr dengan simpangan baku 10,54 gr. Setelah sampai di lokasi dilakukan aklimatisasi dalam kolam selama 24 jam.

\subsection{Pembesaran Lobster}

a. Penempatan Kompartemen Dasar Lobster Kompartemen diikatkan pada pemberat yang terbuat dari beton, kemudian diletakkan di area pantai sepanjang yang berkontur kubangan sehingga terlindung dari gelombang di saat air laut pasang. Sedangkan pada saat air laut surut di area kubangan ini masih terdapat air laut. Penempatan kompartemen dasar lobster di lokasi penelitian ditunjukkan dalam Gambar 2.

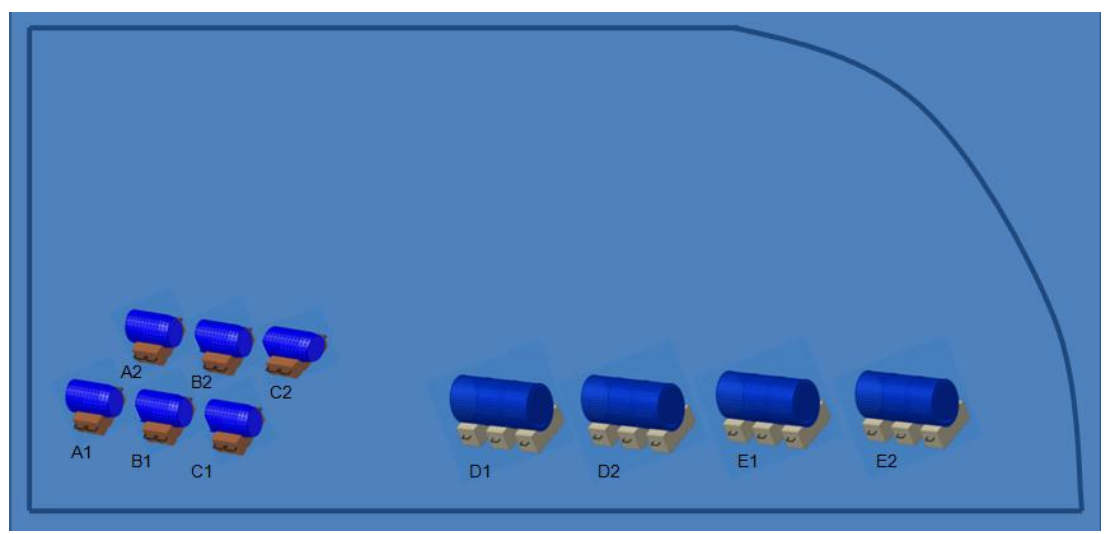

Gambar 2. Penempatan kompartemen dasar lobster di lokasi penelitian

Figure 1. The placement of fixed cage at the study site Sumber: Hasil perancangan

b. Pembesaran Lobster

Pembesaran lobster dalam kompartemen dilakukan dengan terlebih dahulu meletakkan kompartemen beserta pemberatnya di lokasi budidaya. Pengambilan data berat lobster dilakukan selama 42 hari dengan interval 7 hari. Masing-masing kompartemen diambil 2 sampel lobster dari masing-masing kompartemen untuk diukur panjang karapaks dan beratnya secara acak. Pemeliharaan lobster dengan memberi makan 1 kali sehari sesuai waktu surut perairan Pantai Sepanjang dengan jenis makanan yang bervariasi yaitu kerang hijau, gurita dan ikan rucah, pemberian pakan ditakar sebanyak 30-40 \% berat lobster di dalam kompartemen dasar.

c. Pengambilan data kualitas fisik perairan Pengambilan data kualitas fisik perairan meliputi data kecepatan gelombang, suhu permukaan, salinitas, kecerahan air, kedalaman, Dissolved Oxygen (DO) dan $\mathrm{pH}$.

\subsection{Analisis Data}

a. Penentuan kecepatan pertumbuhan panjang dan berat lobster

Data berat dan panjang lobster yang didapatkan kemudian dikorelasikan 
dengan waktu budidaya (umur pembesaran lobster). Berat dan panjang lobster diduga akan menghasilkan fungsi linear saat dihubungkan dengan waktu budidaya.

Persamaan umum fungsi linear adalah (Sugiyono, 2011):

$\mathrm{f}(\mathrm{x})=\mathrm{ax}+\mathrm{b}$

Dimana:

$\mathrm{f}(\mathrm{x})=$ Variabel terikat

$\mathrm{X}=$ variabel bebas

$\mathrm{a}=$ konstanta

$\mathrm{b}=$ intersep $\{$ harga $\mathrm{f}(\mathrm{x})$ jika $\mathrm{x}=0\}$

Nilai konstanta (a) merupakan koefisien regresi atau gradien atau kemiringan (Sugiyono, 2008). Nilai konstanta (a) menentukan kemiringan garis fungsi $\mathrm{x}$ curam atau landai. Semakin curam garis maka semakin besar pula nilai konstanta (a). Semakin besar nilai koefisien regresi atau gradien dapat digunakan sebagai indikator kecepatan pembesaran lobster. Dalam penelitian ini, semakin curam garis fungsi $\mathrm{x}$ maka akan didapatkan nilai konstanta (a) atau gradien yang semakin besar yang berarti semakin cepat pula pembesaran yang terjadi.

b. Penentuan tipe kompartemen yang paling efektif untuk pembesaran lobster

Tipe kompartemen yang paling sesuai untuk pembesaran lobster dapat ditentukan dengan membandingkan nilai koefisien regresi panjang dan berat lobster terhadap waktu budidaya pada tiap tipe kompartemen, baik kompartemen kontrol maupun kompartemen yang telah dimodifikasi. Koefisien regresi panjang dan berat kontrol didapatkan dari data panjang dan berat lobster yang dibesarkan pada kompartemen yang memiliki tipe yang sama dengan yang digunakan masyarakat. Nilai koefisien regresi yang paling besar menunjukkan kecepatan pembesaran yang paling tinggi, artinya kompartemen tersebut paling sesuai untuk pembesaran lobster.

\section{HASIL DAN PEMBAHASAN}

Pantai Sepanjang, Kabupaten Gunung Kidul merupakan pantai karst yang langsung berhubungan dengan Samudera Hindia sehingga mempunyai energi gelombang yang kuat yaitu 43,3 $\mathrm{m} / \mathrm{dt}$ (Damayanti \& Ranum, 2008). Penelitian tahun 2008 oleh Damayanti et al. di pantai karst Kabupaten Gunung Kidul baru merekomendasikan pemanfaatan Pantai Sepanjang sebagai daerah budidaya rumput laut/tanaman obat dan wisata alam. Sekitar tahun 2010 usaha pembesaran lobster laut mulai dikembangkan di wilayah Pantai Sepanjang dengan menggunakan kolam di dalam ruangan dan kompartemen dasar. Struktur dasar Pantai Sepanjang adalah batu karang dan pasir putih. Pada struktur batuan karang terdapat beberapa zona berbentuk kubangan/kolam yang pada saat surut zona tersebut masih terdapat genangan air laut. Kondisi ini sesuai sebagai lokasi pembesaran lobster (Thao, 2012).

Pengukuran kualitas fisik perairan Pantai Sepanjang menunjukkan bahwa lokasi ini memenuhi persyaratan sebagai lokasi budidaya seperti terlihat pada Tabel 3 .

Tabel 3. Kesesuaian kualitas fisik perairan pantai sepanjang sebagai lokasi budidaya

Table 3. Suitability of physical water quality in Sepanjang Beach as location of mariculture

\begin{tabular}{lcc}
\hline \multicolumn{1}{c}{ Parameter } & $\begin{array}{c}\text { Hasil Pengukuran } \\
\text { Parameter }\end{array}$ & Kriteria Baku *) \\
\hline Gelombang & Kurang dari $2 \mathrm{~m}$ & Kurang dari $2 \mathrm{~m}$ \\
Suhu permukaan air $\left({ }^{\circ} \mathrm{C}\right)$ & $26,88-28,03$ & $26-32$ \\
Salinitas $(\%$ oo & $32.56-34.27$ & Fluktuasi $<3$ \\
Kecerahan air $(\mathrm{cm})$ & $76-98$ & Lebih dari $3 \mathrm{~m}$ \\
Kedalaman air $(\mathrm{cm})$ & $76-98$ & Lebih dari 5 \\
DO (mg/l) & $4.82-5.52$ & $4-6$ \\
pH & $7.34-7.84$ & $7-9$ \\
Sumber: Hasil pengukuran & & \\
& $*$ ) Gunarso (1985); Ahmad et al. $(1991)$ dan Imanto (2000).
\end{tabular}

Uji Efektivitas Kompartemen Dasar untuk Pembesaran Lobster Pasir (Panulirus homarus) di Pantai Sepanjang, Kabupaten Gunung Kidul - Umi Anissah, Amin Pamungkas, Waryanto dan Sri Suryo Sukoraharjo 
Tabel 3 menunjukkan bahwa parameter kualitas fisik perairan masih berada pada kisaran yang layak untuk dijadikan lokasi pembesaran lobster dalam kompartemen dasar. Adanya hamparan batu karang yang terbentang membentuk pulau-pulau karang dan adanya cekungan diantara batu karang, melindungi pembesaran lobster keramba dasar dari gelombang dan arus keras yang berasal dari Samudera Hindia. Karang berpasir, merupakan lokasi yang cukup ideal untuk lokasi budidaya laut. Rentang suhu perairan tidak fluktuatif, yaitu berkisar antara 26,88-28,03 ${ }^{\circ} \mathrm{C}$, sesuai untuk kegiatan budidaya (Gunarso, 1985; Ahmad et al., 1991 dan Imanto, 2000).

Pemilihan bibit lobster pasir yang akan dibesarkan dalam kompartemen tidak memperhatikan perbandingan jumlah lobster jantan dan betina. Hubungan panjang dan berat lobster tidak dipengaruhi oleh perbedaan jenis kelamin. Hal ini berdasarkan hasil penelitian dengan spesies lobster pasir (Hargiyanto et al., 2013) dan spesies lobster batu (Fauzi et al., 2013) bahwa tidak ada perbedaan yang nyata hubungan panjang berat antara jantan dan betina sehingga untuk perhitungan panjang dan berat data dapat digabungkan.

Tabel 2 memperlihatkan jumlah lobster yang dibesarkan dalam tiap kompartemen lobster. 10 ekor lobster dibesarkan untuk kompartemen dengan volume 30 liter, jumlah ini mendekati jumlah lobster yang dibesarkan dalam kompartemen kontrol 30 liter yaitu 9 ekor. Jumlah tidak bisa disamakan karena keterbatasan ketersediaan bibit. Sedangkan dalam kompartemen 200 liter, dibesarkan lobster dengan jumlah 15 ekor atau 50\% lebih banyak daripada kompartemen 30 liter. Dengan demikian, kepadatan lobster pada kompartemen 30 liter adalah 1/3 lobster/lt atau 0,33 lobster/lt, sedangkan kepadatan lobster pada kompartemen 200 liter adalah 3/40 lobster/lt atau 0,075 lobster/lt. Dilihat dari nilai kepadatan lobster, hipotesa yang dikembangkan adalah bahwa lobster pada kompartemen 200 liter akan memiliki pertumbuhan yang lebih cepat daripada lobster pada kompartemen 30 liter dengan asumsi faktor lingkungan periaran dianggap sama atau tidak menjadi pembatas. Semakin luas ruang gerak maka kondisi pembesaran lobster dalam kompartemen semakin mendekati habitat aslinya.
Berat awal lobster pasir yang digunakan dalam penelitian ini antara 20-50 gr. Ukuran ini dipilih karena dalam budidaya lobster, pemindahan lobster dari kompartemen untuk pendederan ke kompartemen pembesaran lobster hingga diperoleh ukuran yang layak dijual adalah pada saat lobster tersebut memiliki berat kurang lebih 30 gr (Williams, 2004).

Pengambilan data berat pada kegiatan pembesaran lobster dalam kompartemen dasar pertama kali diukur pada saat pemindahan lobster dari kolam aklimatisasi ke kompartemen dasar. Selanjutnya data didapatkan dengan mengukur 2 sampel lobster yang diambil secara acak untuk tiap tipe kompartemen dalam interval 7 hari hingga mencapai 42 hari. Selama waktu pembesaran, lobster diberi makanan kerang hijau, gurita dan ikan rucah sebanyak $30-40 \%$ berat lobster di dalam kompartemen dasar berselang seling dengan frekuensi 1 kali setiap hari. Pemberian pakan pada kegiatan budidaya berpengaruh pada kualitas lingkungan perairan karena adanya nitrogen anorganik terlarut dan sisa pakan. Kegiatan pembesaran lobster menggunakan Keramba Jaring Apung (KJA) maupun kompartemen dasar tidak akan berpengaruh buruk terhadap kualitas lingkungan perairan sepanjang tidak dilakukan dengan padat tebar yang sangat tinggi (Leel et al., 2014).

Informasi mengenai kenaikan berat lobster dalam pembesaran kompartemen dasar dilakukan dengan merata-ratakan berat lobster tiap tipe kompartemen pada setiap waktu pengambilan. Gambar 2 menunjukkan kecenderungan kenaikan berat dan panjang karapaks lobster selama masa pembesaran pada kopartemen A. Kompartemen A sebagai kompartemen kontrol, merupakan kompartemen yang sama dengan kompartemen lobster yang selama ini digunakan masyarakat Kab.Gunung Kidul untuk pembesaran lobster pasir. Data dari kompartemen A ini digunakan sebagai kontrol terhadap keberhasilan modifikasi kompartemen yang dilakukan. 


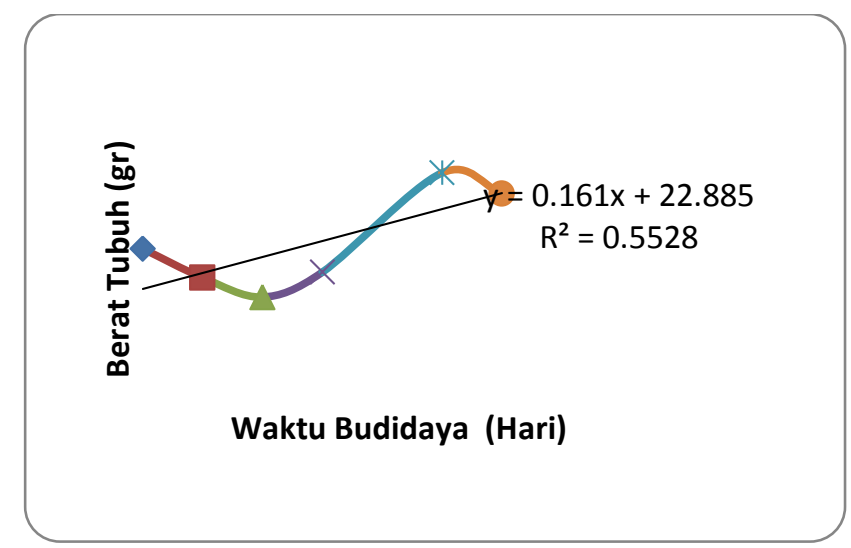

(a)

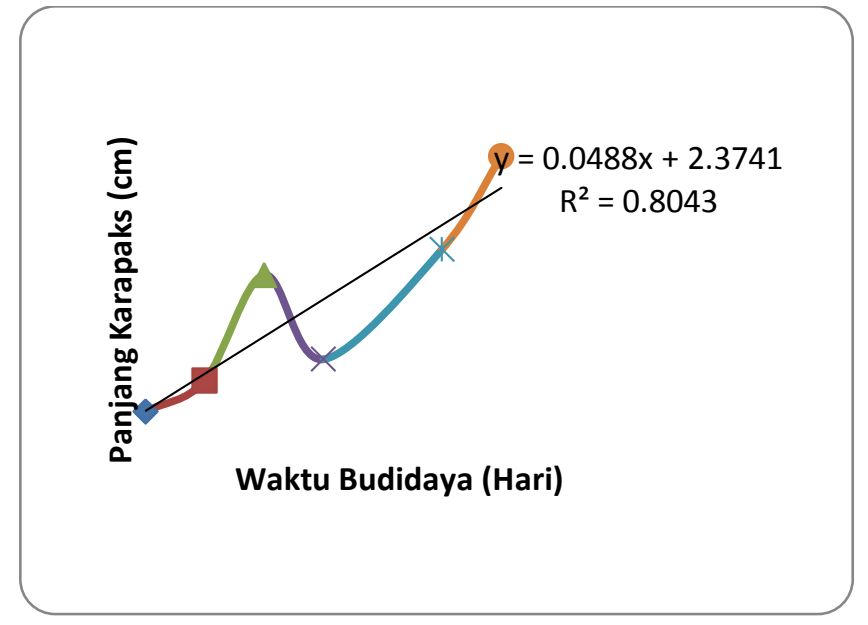

(b)

Gambar 3. Kenaikan berat (a) dan panjang karapaks (b) lobster kompartemen tipe A Figure 3.The weight (a) and carapace length (b) increase of the lobsters in fixed seacage type A Sumber: Hasil pengukuran

Gambar 3 menunjukkan bahwa pembesaran lobster dengan kompartemen seperti yang digunakan selama ini, yaitu silinder plastik HDPE dengan lubang tidak beraturan memiliki angka linearitas 0,552. Dari Gambar 3 diketahui bahwa seri data panjang karapaks dan berat tubuh pembesaran lobster dengan kompartemen kontrol didapatkan 2 persamaan linear, yaitu :

Fungsi panjang karapaks :

$f(x)=0,048 x+2,374$

Fungsi berat tubuh :

$f(x)=0,161 x+22,88$
Nilai konstanta (a) dalam persamaan (2) dan (3) adalah 0,048 dan 0,161. Nilai konstanta (a) ini merupakan konstanta kontrol untuk data panjang karapaks dan berat tubuh karena merupakan data hasil pembesaran lobster menggunakan kompartemen yang selama ini digunakan oleh masyarakat Pantai Sepanjang. Rekayasa kompartemen dasar lobster dinilai memiliki performa yang lebih baik dari performa kompartemen kontrol apabila nilai konstanta (a) untuk panjang karapaks dan berat tubuh lebih besar daripada nilai konstanta (a) panjang karapaks dan berat tubuh kompartemen kontrol. 


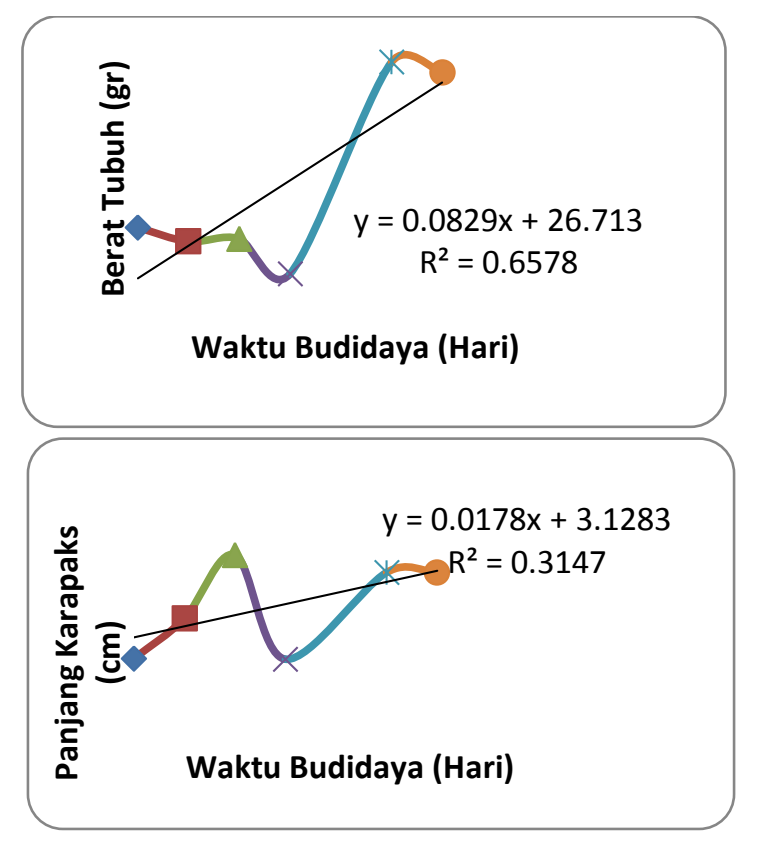

(a)
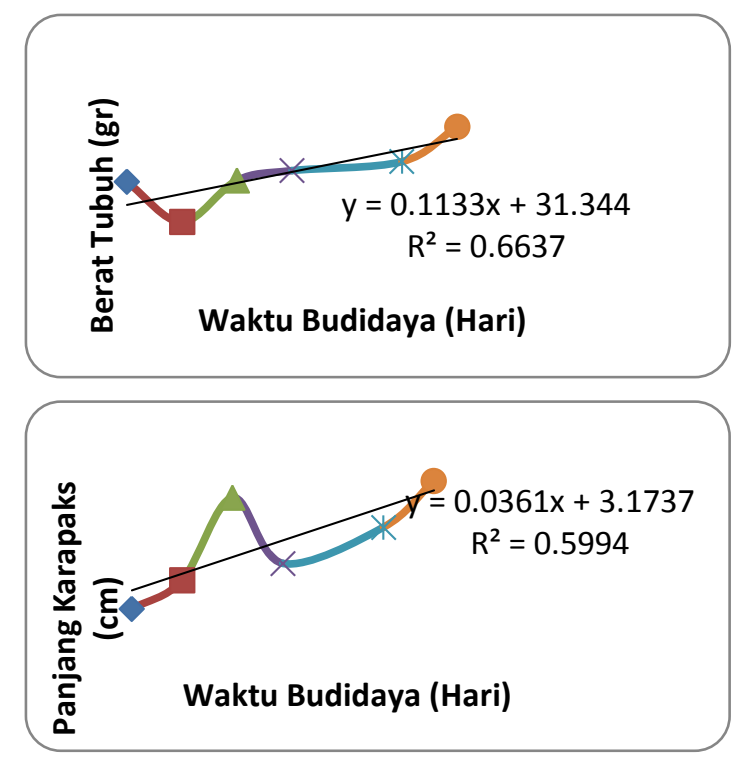

(c)
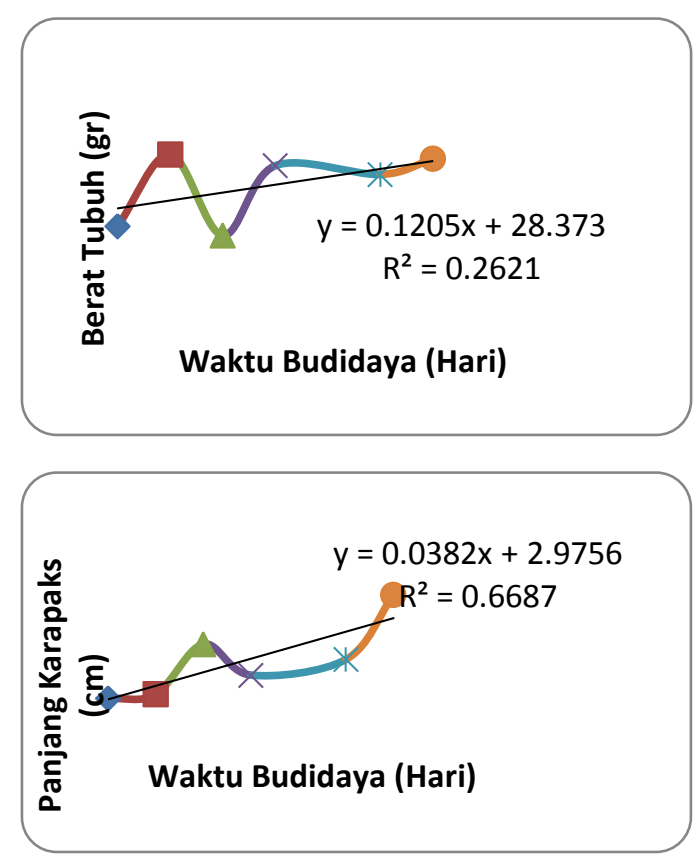

(b)
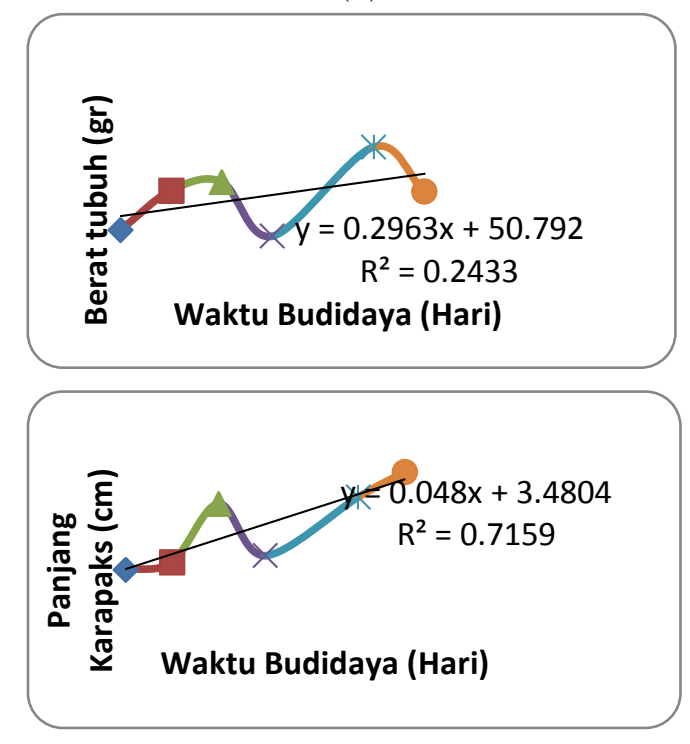

(d)

Gambar 4. Kenaikan berat dan panjang karapaks lobster (a). Kompartemen tipe B; (b). Kompartemen tipe C; (c). Kompartemen tipe D; (d). Kompartemen tipe E

Figure 4. The weight and carapace length increase of the lobsters (a). Fixed seacage type B (b). Fixed seacage type C; (c) Fixed seacage type D; (d) Fixed seacage type E Sumber: Hasil pengukuran

Gambar 4(a) dan 4(b) menunjukkan kenaikan berat badan dan panjang karapaks lobster yang dibesarkan dalam kompartemen tipe B dan C. Kompartemen tipe $\mathrm{B}$ dan $\mathrm{C}$ berbentuk silinder berukuran 30 liter. Kompartemen B memiliki lubang pada selimutnya dengan diameter lubang 2 $\mathrm{cm}$, sedangkan kompartemen $\mathrm{C}$ memiliki lubang dengan diameter $3 \mathrm{~cm}$. Kedua tipe kompartemen ini diisi lobster dengan jumlah mendekati jumlah lobster pada kompartemen kontrol seperti terlihat pada Tabel 2. Perekayasaan terletak pada keteraturan pembuatan lubang dan diameter lubang 
untuk sirkulasi air. Dilihat dari konstanta persamaan (a) yang didapatkan, maka terlihat bahwa rekayasa kompartemen tipe $\mathrm{B}$ dan $\mathrm{C}$ menunjukkan performa yang tidak lebih baik daripada kompartemen kontrol.

Gambar 4(c) dan 4(d) menunjukkan kenaikan berat badan dan karapaks lobster yang dibesarkan dalam kompartemen tipe D dan E. Kompartemen tipe D dan E berbentuk silinder berukuran 200 liter. Kompartemen D memiliki lubang pada selimutnya dengan diameter lubang $2 \mathrm{~cm}$, sedangkan kompartemen $\mathrm{E}$ memiliki lubang dengan diameter $3 \mathrm{~cm}$. Kedua tipe kompartemen ini diisi lobster dengan jumlah lebih banyak $50 \%$ daripada kompartemen yang berukuran 30 liter. Perekayasaan kompartemen dari kompartemen kontrol terletak pada keteraturan pembuatan lubang, diameter lubang untuk sirkulasi air dan perbesaran volume. Dibandingkan dengan nilai konstanta karapaks dan berat kompartemen kontrol, nilai konstanta karapaks dan berat lobster kompartemen D masih di bawah kompartemen kontrol. Sedangkan untuk kompartemen E, konstanta berat lebih tinggi daripada kompartemen kontrol, sedangkan bila dilihat dari konstanta karapaks, maka nilai konstanta karapaks kompartemen E sama dengan kompartemen kontrol. Dengan demikian, kompartemen D memiliki performa di bawah kompartemen kontrol, sedangkan kompartemen E memiliki performa di atas kompartemen kontrol. Diduga diameter yang besar dan ukuran silinder sangat mempengaruhi pertumbuhan berat lobster, dengan lebih mudahnya sirkulasi air laut sehingga oksigen terlarut dapat selalu ada dan sisa pakan dapat terbuang lebih lancar/baik

Secara keseluruhan, pembesaran lobster pasir menggunakan kompartemen $\mathrm{E}$ berhasil menambah berat lobster paling besar dibandingkan dengan seluruh kompartemen yang digunakan dalam penelitian ini. Gambar 5 menunjukkan selisih berat rata-rata sebelum dan setelah pembesaran dengan tipe kompartemen yang berbeda. Dari data tersebut diketahui bahwa lobster yang dibesarkan dalam kompartemen E memiliki perbedaan berat yang paling besar yaitu 11,375 gr atau dengan kata lain pada kompartemen E, pertumbuhan berat lobster lebih cepat dibandingkan dengan kompartemen lainnya.

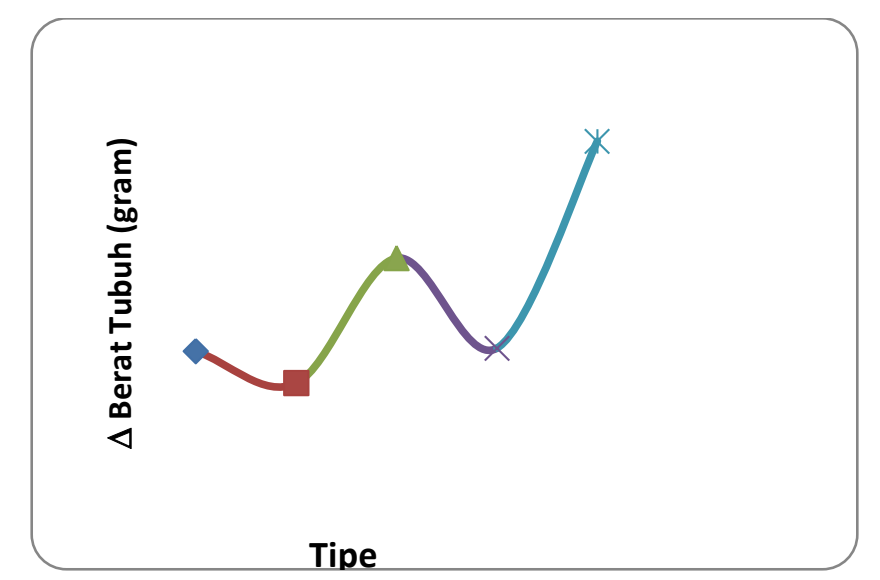

Gambar 5. Pertumbuhan berat lobster menurut tipe kompartemen

Figure 5. The growth of lobster's weight by different type of fixed seacage Sumber: Hasil pengukuran

Dalam penelitian ini, penentuan kompartemen yang paling efektif untuk pembesaran dengan memantau pertumbuhan berat mutlak, yaitu pertumbuhan mutlak yaitu ukuran rata-rata yang dicapai oleh lobster dalam satuan waktu tertentu. Sedangkan pemantauan data pertumbuhan berat nisbi yang merupakan ukuran panjang atau berat yang dicapai dalam periode pembesaran yang di hubungkan dengan panjang atau berat pada sebelum periode pembesaran (Pusluh KKP, 2011) tidak dilakukan.

Pertumbuhan secara umum dipengaruhi oleh dua faktor, yaitu faktor internal dan faktor eksternal. Faktor internal meliputi sifat genetis dan kondisi fisiologi. Sementara faktor eksternal berkaitan dengan lingkungan yang menjadi media pemeliharaan, antara lain kimia air, substrak dasar, 
suhu air, dan ketersediaan pakan (Pusluh KKP, 2011). Penelitian ini merekam pertumbuhan lobster pasir yang diakibatkan faktor eksternal berupa kompartemen dasar lobster. Faktor eksternal lain seperti kimia air, substrat dasar, suhu air dianggap tidak berbeda karena keseluruhan kompartemen lobster ditempatkan di satu lokasi. Tingkat ketersediaan pakan dianggap sama karena seluruh kompartemen diberikan variasi makanan yang sama dengan prosentase yang sama. Faktor internal pertumbuhan yang meliputi sifat genetis dan kondisi fisiologi sama lobster dengan berat 20 gr dan 50 gr dikatagorikan sebagai benih yang memiliki bentuk sama dengan lobster dewasa (Yusnaini et al., 2009; Halthius, 1981). Keseluruhan bibit lobster didatangkan dari Lombok, NTB dan memiliki kesamaan spesies yaitu lobster pasir (Panulirus homarus). Hasil penelitian menunjukkan secara umum bahwa hipotesa yang dikembangkan benar, bibit lobster yang dibesarkan dalam kompartemen yang berukuran 200 lt dengan diameter lubang $3 \mathrm{~cm}$ memiliki tingkat pertumbuhan berat yang lebih cepat dibandingkan kompartemen lainnya.

Pembesaran lobster di Pantai Sepanjang menggunakan kompartemen dasar yang paling optimum dapat meningkatkan berat lobster dengan kecepatan pertumbuhan 0,27 gr/hari. Bila dibandingkan dengan percepatan pertumbuhan lobster menggunakan desain kompartemen di beberapa negara lain, percepatan pertumbuhan menggunakan kompartemen dasar di Pantai Sepanjang masih di bawah pertumbuhan lobster di negara lain. Pembesaran lobster di India mampu membesarkan lobster dengan kecepatan pertumbuhan 0,89 gr/hari (Vijayakumaran et al., 2009) sedangkan di Filipina, pertumbuhan lobster dengan keramba meningkatkan berat lobster sebesar 2,70 gr/hari (Philipose et al., 2012).

Pertumbuhan lobster pasir di Pantai Sepanjang memiliki pola pertumbuhan allometrik negatif. Hal ini diketahui dengan mengolah data panjang dan berat lobster berdasarkan persamaan yang dinyatakan oleh Bal \& Rao (1984) dan King (1995):

$$
\mathrm{W}=\mathrm{aL}^{\mathrm{b}}
$$

dimana W adalah berat lobster (gr), L adalah panjang karapas $(\mathrm{mm})$, a adalah konstanta dan $b$ adalah nilai eksponensial. Nilai b yang diperoleh digunakan untuk menentukan pola pertumbuhan. Jika nilai $b=3$ berarti pola pertumbuhan bersifat isometrik, $\mathrm{b}<3$ pola pertumbuhan bersifat allometrik negatif dan $b>3$ pola pertumbuhan bersifat allometrik positif.

Hubungan antara panjang dan berat lobster pasir yang dibudidayakan di Pantai Sepanjang ditunjukkan pada Gambar 6.

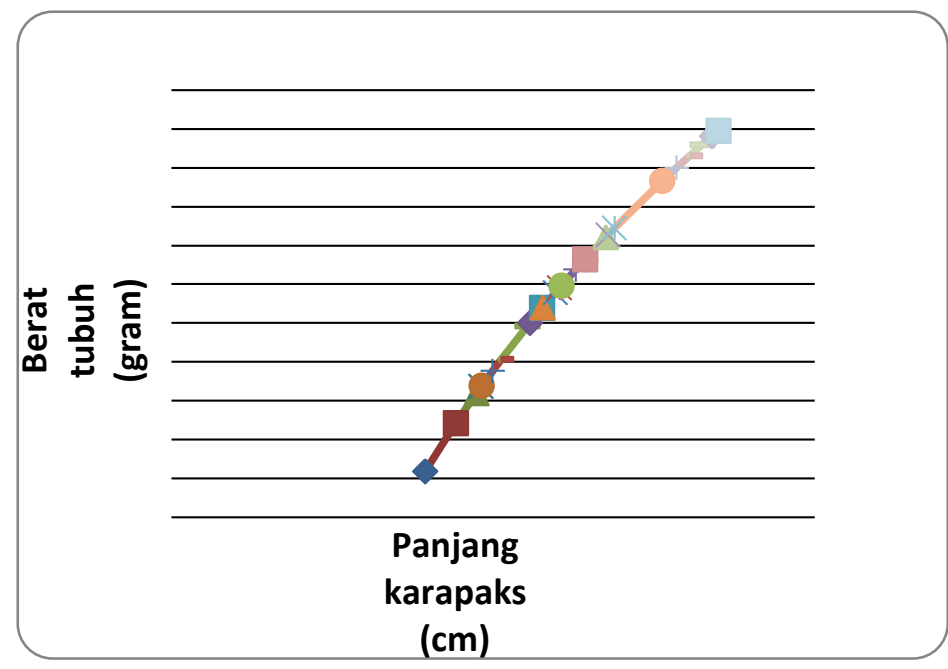

Gambar 6. Hubungan berat dan panjang karapaks lobster pasir Figure 6. Length-weight relationship of spiny lobster Sumber: Hasil analisis 
Dari grafik didapatkan persamaan :

$$
\mathrm{y}=3,07468 \mathrm{x}^{0,15346}
$$

maka diketahui nilai $\mathrm{b}=0,15346$ (nilai $\mathrm{b}<3$ ). Dengan demikian dapat digolongkan pola pertumbuhan lobster pasir bersifat allometrik negatif yang berarti pertambahan panjang karapaks lobster lebih cepat daripada pertambahan beratnya. Hal ini sesuai dengan hasil penelitian yang dilakukan oleh Aisyah et al. (2009), Aisyah \& Setya (2010) dan Hargiyanto et al. (2013) mengenai pola pertumbuhan lobster pasir di pesisir Yogyakarta yang memiliki pola allometrik negatif.

\section{KESIMPULAN DAN SARAN}

\section{Kesimpulan}

Kondisi parameter perairan Pantai Sepanjang, Kabupaten Gunung Kidul, Yogyakarta, sesuai untuk kegiatan budidaya pembesaran lobster laut dengan pola pertumbuhan allometrik negatif. Kompartemen dasar bentuk silider dengan volume 200 liter dan diameter $3 \mathrm{~cm}$ dapat digunakan dalam pembesaran lobster di perairan ini, sesuai dengan kontur dasar dari perairan. Metode pemantauan pertumbuhan mutlak pada pengukuran berat dan panjang karapaks dapat digunakan sebagai uji coba efektifitas kompartemen dasar untuk pembesaran lobster pasir.

\section{Saran}

Kegiatan kompartemen dasar ini perlu dilakukan penelitian lanjutan untuk melihat tingkat keberhasilan kompartemen dasar bentuk silinder ini dengan kondisi dan kontur perairan yang berbeda.

\section{UCAPAN TERIMA KASIH}

Kegiatan ini merupakan hasil riset Rekayasa Teknologi dalam Mendukung Industrialisasi Perikanan yang dilaksanakan di Pantai Sepanjang, Kabupaten Gunung Kidul, Tahun Anggaran 2014, Pusat Pengkajian dan Perekayasaan Teknologi Kelautan dan Perikanan. Ucapan terima kasih disampaikan kepada Kepala Pusat Pengkajian dan Perekayasaan Teknologi Kelautan dan Perikanan, Kepala Dinas Kelautan dan Perikanan Propinsi Daerah Istimewa Yogyakarta, Kepala Dinas Kelautan dan Perikanan Kabupaten Gunung Kidul dan semua pihak yang telah membantu terlaksananya kegiatan penelitian ini.

\section{DAFTAR PUSTAKA}

Achmad, T., Imanto, P.T., Muchori, M., Basyarie, A., Sunyoto, P., Slamet, B., Mayunar, Purba, R., Diani, S., Rejeki, S., Pranowo, S.A., \& Murtiningsih, S. (1991). Pedoman teknis operasional pembesaran kerapu dalam keramba jaring apung. Maros: Balai Penelitian Perikanan Pantai.

Aisyah, Badrudin \& Triharyuni, S. (2009). Lobster seed resources in south coast of Yogyakarta. AARD. MMAF. (Laporan tidak dipublikasikan)

Aisyah, \& Triharyuni, S. (2010). Production, size distribution and length-weight relationship of lobster landed in south coast of Yogyakarta, Indonesia. Ind. Fish. Res. J., 16(1), 15-24.

Bal, D.V., \& Rao, K.V. (1984). Marine fisheries. Tata Mc. Graw-Hill Publishing Company Limited, New Delhi.

Damayanti, A., \& Ranum, A. (2008). Karakteristik fisik dan pemanfaatan pantai karst Kabupaten Gunung Kidul. Jurnal Makara Teknologi, 12(2), 91-98.

Fawzi, M., Andhika, P.P., Ignatius, T.H., Fayakun, S., \& Andria, A.U. (2013). Hubungan panjang-berat dan faktor kondisi lobster batu (Panulirus penicillatus) di perairan selatan Gunung Kidul dan Pacitan. BAWAL, 5(2), 97-102.

Gunarso, W. (1985). Tingkah laku ikan dalam hubungannya dengan alat, metode dan taktik penangkapan. Bogor: Fakultas Perikanan IPB.

Hargiyanto, I.T., Fayakun, S., Andika, P.P., \& Fauzi, M. (2013). Hubungan panjang-berat dan faktor kondisi lobster pasir (Panulirus homarus) di perairan Yogyakarta dan Pacitan. BAWAL, 5(1), 41-48.

Holthuis, L.B. (1981). FAO Species Catalogue. Vol. 13. Marine lobsters of the world. An annotated and illustrated catalogue of species of interest to fisheries known to date. FAO Fisheries Synopsis. 13 (125): 292.

Hung, L.V., \& Tuan, L.A. (2009). Lobster seacage culture in Vietnam. In 'Spiny lobster aquaculture in the Asia-Pacific region', ed. by K.C. Williams. ACIAR Proceedings No. 132, 10-17. Canberra: Australian Centre for International Agricultural Research.

Imanto, P.T. (2000). Budidaya ikan laut. Loka Gondol: Penelitian Perikanan Pantai.

Jeffs, A., \& Davis, M. (2003). An assessment of the aquaculture potential of the Carribean spiny lobster, Panulirus argus. Proceeding of Gulf Caribbean Fisheries Institute. 54, 413-426. 
Jeffs, A.G. \& James, P. (2001). Sea-cage culture of the spiny lobster Jasus edwardsii in New Zealand. Journal of Marine and Freshwater Research, 52, 1419-1424.

Jones, C. (2008). Studi kelayakan: Meningkatkan pembesaran dan nutrisi lobster di Nusa Tenggara Barat. Laporan penelitian ACIARSADI. Australia Indonesia partnership.

King, M. (1995). Fisheries biology, assessment and management. Fishing New Books.

Lee, S., Hartstein, N.D., \& Jeffs, A. (2014). Modelling carbon deposition and dissolved nitrogen discharge from sea cage aquaculture of tropical lobster. Journal of Marine Science. UK: Oxford.

Mohammed, G., Syda Rao, G. \& Ghosh, S. (2010). Aquaculture of spiny lobsters in sea cages in Gujarat, India. J. Mar. Biol. Ass. India, 52 (2): 316-319.

Philipose, K.K., Jayasree, L.S.R., Krupesha, S., \& Divu D. (2012). Open sea cage culture. Handbook. Central Marine Fisheries Research Intitute. Karwar Research Centre. India.

Pusat Penelitian Pengelolaan Perikanan dan Konservasi Sumberdaya Ikan (P4KSI). (2012). Developing new assessment and policy framework for indonesia's marine fisheries, including the control and management of illegal, unregulated and unreported fishing. Laporan Teknis. $111 \mathrm{p}$.

Pusluh KKP. (2011). Materi Penyuluhan Kelautan dan Perikanan. Pusat Penyuluhan Kementerian Kelautan dan Perikanan. www.pusluh.kkp.go.id/index.php/arsip/.../lobster. pdf/

Sugiyono. (2011). Metode penelitian kuantitatif, kualitatif dan $R \& D$. Bandung: CV. Alphabeta.

Sugiyono. (2008). Metode penelitian bisnis. Cetakan keduabelas 2008. Bandung: CV. Alphabeta.

Thao, N. (2012). Opportunities and challenges in lobster marine aquaculture in Vietnam: the case of Nha Trang Bay. Master Thesis. The Norwegian College of Fishery Science. University of Tromso, Norway \& Nha Trang University, Vietnam.

Vijayakumaran, M., Vankatesan, R., Murugan, S.T., Kumar, T.S., Kumar, J.H.A.D., Remany, M.C., Thilakam, J.M.L., Jahan, S,S., Dharani, S., Kahtiroli, \& Selvani, K. (2009). Farming of spiny lobster in sea cages in India. New Zealand Journal of Marine and Freshwater Research, 43(2), 623-634.

Willams, K.C. (2004). Spiny lobster ecology and exploitation in the South China Sea region. Proceedings of a workshop held at the Institute of Oceanography. Nha Trang, Vietnam.

Yusnaini, Nessa, M.N., Djawad, M. I., \& Trijuno, D.D. (2009). Ciri Morfologi Jenis Kelamin dan Kedewasaan Lobster Mutiara Panulirus ornatus.
Torani Jurnal Ilmu Kelautan dan Perikanan, 19(3), 166- 174. 